\title{
Obituary
}

\section{Professor \\ F. J. W. Roughton}

THE recent death of Professor Francis John Worsley Roughton, FRS, brought to an end a scientific career which was unusual in its length of active and useful scientific work. It was more unusual in the breadth of interests represented, and quite exceptional in the number of separate, but related, new fields of scientific interest it opened up. Any one of these might have filled the working span of a lesser man, and each now has its own group of workers developing basic observations or ideas first put forward by Roughton. Curiously, there is no significant group of this kind in England, and this may have contributed to the relatively slight recognition his work received at home, compared with that given it abroad, especially in the United States.

Much of Roughton's work was concerned with time-dependent phenomena, and his first research project, with Professor $\mathrm{H}$. Hartridge, was to measure the velocity with which oxygen combines with haemoglobin. To do this they developed the continuous flow rapid reaction method in which two liquids, in this case deoxyhaemoglobin and a solution of oxygen, were rapidly mixed together, and the streaming liquid viewed at varying distances along an observation tube, the distance serving as a measure of the time elapsed since mixing of the liquids. This work was done before photoelectric cells were generally available, and the ingenious method bore no relation to later procedures. It was quite otherwise with the principle, which has been developed by a series of workers, including G. A. Millikan and B. Chance, and culminated in the stopped-flow apparatus which has become an everyday laboratory instrument used in many chemical and biological disciplines. Interestingly, the time resolution achieved with the original apparatus was of the same order as that of its later descendants. There is a natural limit to what can be done with reasonable laboratory liquid driving pressures, and this limit was attained in a single stride.

Since Roughton's original intent had been to succeed his father (and four previous Roughtons) as a medical practitioner at Kettering, it was natural that he should turn to the physiological problem of gas exchange in heterogeneous systems once he had learnt that the oxygen reaction was rapid com- pared with the time the erythrocyte spends in the capillaries. The combination of chemical reaction and diffusion in the erythrocyte continued to interest him for the remainder of his life, though he and his mathematical colleagues were handicapped by the lack of effective computing facilities. A further extension of interest to the reactions of carbon dioxide soon followed, and, having first shown that a catalyst of the $\mathrm{CO}_{2}$, water, carbonic acid reaction must be present in blood, he proceeded, with Meldrum, to work on carbonic anhydrase, and to develop the theory of carbon dioxide transport in blood. This work was summarized in an article in Physiological Reviews in 1935 which is still full of interest today. At about the same time he obtained evidence of the formation of carbamino haemoglobin by direct reaction of $\mathrm{CO}_{2}$ with amino groups in the protein. The significance and validity of these observations were questioned for some time, but in the past 10 years, with Professor L. Rossi-Bernardi of Milan, the original observations were fully substantiated, and, making use of the new structural knowledge of the haemoglobin molecule, the dissociation constants of the active groups in the $\alpha$ and $\beta$ chains were determined, and the interaction of $\mathrm{CO}_{2}$ with 2,3-diphosphoglycerate defined. This was the work in which he was engaged at the time of his death and the most recent results have not yet been published.

The flow of his career was interrupted by a period of war-related research at Harvard, and, following his return to England and appointment to the chair of colloid science at Cambridge, he took up again the problem of determining the oxygen dissociation curve with sufficient accuracy to permit the evaluation of the four Adair constants which must describe the equilibrium of a tetrameric molecule. This involved the development of specially precise gasometric methods applicable to the extremes of the curve, up to 2 per cent saturation, and above 98 per cent saturation. The results showed that the equilibrium cannot be fully described by a simple two state model, such as that considered by Forbes and Roughton in 1931, in which a single conformation change occurs after three ligand molecules have been bound. $\mathrm{He}$ was, in general, sceptical about models, feeling that history had not been kind to those who forced the behaviour of haemoglobin into a predetermined mould: During this later period he continued his contacts with his colleagues in the United States, and was concerned especially with projects of a physiological character. In all this work he had many colleagues and collaborators, and with continued bench work, his activities made for a full schedule which he continued, and delighted in, up to the very end of his life.

\section{Professor B. G. Anan'ev}

ProfESSOR BORIS GERASIMOVICH ANAN'EV, Dean of the Faculty of Psychology of Leningrad University, and one of the leading psychologists of the Soviet Union, died on May 18, 1972, after a short illness.

Anan'ev was born on August 14, 1907, in Vladikavkaz (now Ordzhonikidze). He graduated from the Gor'kii Pedagogic Institute in Vladikavkaz in 1928 , and proceeded from there to a research course at the Bekhterev Brain Institute in Leningrad. After completing his postgraduate studies in 1930, he remained at the Bekhterev Institute until 1942. During the Second World War he was head of the psychological laboratory of a military casualty hospital. For the rest of his life his work was closely connected with Leningrad University, where he became a head of department and then Dean of the Faculty of Psychology. In 1951 he became head of the Institute of Pedagogic Research of the Academy of Pedagogic Sciences of the RSFSR (now the Academy of Pedagogic Sciences of the USSR) He was a member of the Praesidium of the Society of Psychologists of the USSR, a member of the Bureau of the Department of Psychology and Growth Physiology of the Academy of Pedagogic Sciences of the USSR, and a member of the Editorial Board of Voprosy Psikhologii.

Professor Anan'ev's principal fields of research were the study of sensations, transitions from sensory perceptions to thought, pedagogic psychology, psychopathology, growth psychology, and the history of psychology in Russia. His works include: $K$. teorii vnutrennei rechi $v$ psikhologii (Towards a theory of inner speech in psychology) (1946); Materialy $k$ psikhologicheskoi teorii oshchushcheniya (Materials for a psychological theory of sensation) (1948); Assotsiatsiya oshchuschenii (Association of sensations) (1955); and, 